DOI: $10.20472 /$ IAC.2017.034.015

\title{
RODOLFO DELGADO
}

Tokai University, Japan

\section{TEACHING INTERCULTURAL COMMUNICATION COMPETENCE TO ARABIAN STUDENTS}

\begin{abstract}
:
This paper aims to provide task-based activities for teaching intercultural communication to students of the Arabic world. Students from Saudi Arabia, United Emigrates Arabs, and Qatar were among the students that participated in the business writing, and discussions on intercultural communication courses. Based on Islamic religious believes, people think of religion before doing businesses nationally and internationally.

"Islam is often perceived to be an impediment to business, with the economies of most Muslim states underdeveloped and only five out of the FT Global 500 leading companies by market capitalization based in the Islamic world. Legal uncertainties arising at the interface of traditional Islamic shariah jurisprudence and Western contract law deter foreign direct investment in predominately Muslim states (Ballantyne, 1997). Islamist political movements are usually viewed negatively by business, as they are perceived to be a threat to security and stability, and add to country risk" (Wilson, 2006).

Task-based activities for intercultural communication will be discusses to improve their competence doing business nationally and internationally. Problem solving, critical thinking, role playing, group discussion, and debate are some of the learning strategies that will be discussed to examine the effectiveness in improving Arabian university students' language proficiency and the effectiveness of class management in a Japanese private university.

Teachers and professors are constantly looking for strategies, techniques, and practices to better the learning environment. Providing the right balance of theory and practice can fully engage students to improve their performance in classroom. Examples of the learning skills shared with students will be discussed.

Task-based activities represent important keys for developing intercultural communication competence and improving second language acquisition for courses like business writing, interactive English, and discussions on intercultural communication. Students had access to professionals' analytical skills to understand the behavior, attitudes, body language, and know-how of western cultures compared to Arabian cultures.
\end{abstract}

\section{Keywords:}

Teaching, learning, strategies, techniques, tasks, business, English, Intercultural, Communication

JEL Classification: A00 